\title{
KEMAMPUAN ANAK PRASEKOLAH MENGINGAT KOSA KATA DITINJAU DARI METODE PENYAJIAN MATERI PELAJARAN
}

\author{
Arief Fahmie \\ Universitas Islam Indonesia
}

\section{WTISARI}

Penelitian ini bertujuan mengetahui secara empiris metode penyajan materi kosa kata baru, dalam hal ini kosa kata bahasa lnggris, yang tepat diberikan kepada anak prasek olah of Tam Kanak-kanak Al-Qur'an. Hipotesis penelitian ini adalah ada perbedaan efektivitas metode penyajian materi peiajaran, yaitu metode awai-akhir, metode awairtengah, dan metode tengahakhir terhadap kemampuan anak prasekolah mengingat materi peiajaran berupa kosa kała bahasa inggris. Metode tengah-akhir akan menghasilkan skor yang lobih tinggi dampada metode awai-akhir dan metode awai-tengah.

Subjek peneitian ini adaiah santri Madrasah Diniyath Al-Qur'an Aisyiah (MDAA) Tegairejo, Yogyakarta yang berusia 5-6 tahun, bohm pemah mengikuti kursus bahasa inggris, dan belum pemah menerima pelajaran bahasa inggris d sekolah. Subjek berjumiah 31 orang. Alat ukur yang digunakan daiam penelitian ini adalah Tes Kemampuan Mengingat Kosa Kata Bahasa inggris. angkef berisi pertany.aan-pertany.aan tentang kendisi lingkungan rumah subjek yang berkaitan dengan pengenalan bahasa inggris dan gambar yang merupakan materi pelajaran kesa kata bahasa inggris sebanyak 48 buah.

Hasil penelitian menunjukkan bahwa terdapat perbedaan yang sangat signifikan antara metode awai-tengah, metode awai-akhl, dan metode tengahakhir. Analisis data dengan menggunakan anava amatan viangan 1-faktor menunjukkan nilia sebesar FaA sebesar 15,618 dengan $p<0,01$. Hasil selanjutnya menunjukkan bahwa metode aw ai-akhir dan metode tengah-akhir menunjukkan hasil yang lebih baik danipada metode awal-tengah, sedargkan antara metede awal-akhir dan metode tengah-akhir tidak menunjukkan perbedaan.

Kata Kunci: Anak Prasekolah, Kosa Kata, Metode Penyajian

Arief Fahmie adalah dosen Fakultas Psikologi Uiniversitas Islam Indonesia. Lulus Sarjana Psikologi dari Universtias Gadjah Mada Kini sedang mengikuti Program Profesl Psikologi UGM.

\section{PENGANTAR}

$\mathbf{E}$ ksistensi manusia sebagai makhluk sosial tidak dapat terlepas dari kebutuhan berhubungan dengan orang lain. Bahasa merupakan salah satu alat yang digunakan manusia untuk berhubungan dengan orang lain. Sebagai alat komunikasi, bahasa digunakan untuk mengemukakan pikiran maupun perasaan kepada orang lain 
sehingga antar manusia dapat saling memahami.

Pengajaran bahasa pada anak-anak harus mempethatikan tahap perkembangannya. Anak-anak dapat belajar secara mudah dan cepat pada waktu mereka berada dalam critical period atau masa peka. Menurut Brown (dalam Nuryanto, 1997), masa peka berlangsung antara 2-12 tahun. Pada usia 12 tahun dan seterusnya, kemudahan dan kecepatan belajar akan semakin berkurang.

Berkaitan dengan pemberian pelajaran bahasa asing, terdapat kekhawatiran ad any a efek negatif bagi seorang anak yang mengingat kosa kata baru dari bahasa kedua, yaitu kapasitas pemrosesan informasi anak akan penuh sesak. Anak akan mengalami kesulitan karena harus menerima lebih dari satu bentuk informasi kebahasaan (Scarr dkk., 1986). Kekhawatiran tersebut tidak perlu terjadi seandainya dalam pemberian materi pelajaran bahasa diperhatikan faktor-faktor lain, misalnya metode penyampaian, jenis materi, dan sebagainya. Hal ini mengingat kosa kata merupakan suatu proses belajar sehingga perlu diperhatikan faktor-faktor yang mempengaruhi proses belajar dan ingatan, yaitu karakteristik orang yang belajar, aktivitas belajar, kondisi materi, dan kriteria tugas-tugas dalam belajar. Faktorfaktor tersebut berhubungan satu dengan yang lain sehingga membentuk tetrahedral (Jenkins dalam Small, 1990).

Seseorang yang belajar pasti telah mempunyai karakteristik individual yang mempengaruhi ingatan, misalnya motivasi, sikap, inteligensi. Tuntutan dari tugas juga mempengaruhi proses mengingat. Sebagai contoh, tugas-tugas yang bersifat recall (memanggil kembali) memerlukan proses. retrieval yang lebih tinggi dibandingkan yang bersifat recognition (mengenal kembali). Materi tugas mempengaruhi proses ingatan, misalnya ketika suatu materi yang lebih dikenal akan lebih mudah dipelajari daripada materi yang belum pemah dikenal. Aktivitas seseorang yang belajar juga mempengaruhi informasi yang harus disimpan, misalnya mengingat kata dalam jumlah yang banyak memerlukan perhatian yang banyak pula.

Salah satu tempat yang memberikan materi pelajaran untuk mengingat kosa kata baru, dalam hal ini bahasa Inggris, adalah Taman Kanak-kanak A Qur'an, walaupun tidak semua TKA memberikannya. Menurut Saronil (Suara Merdeka, 1 Juli 1996), pada tahun 1996 berdasar data yang ada pada DPP BKPRMt, jumlah TKA di Indonesia telah mencapai 1.200 unit dengan jumlah santri (murid) lebih dari 1.250 .000 anak dengan jumlah pengajar sebanyak 40.000 ustadz/ustadzah (guru). Data lain menunjukkan bahwa jumlah TKATTPA di Indonesia sampai dengan tahun 1997 adalah 36.618 unit (Suara Muhammadiyah, 1997).

DITKA, terdapattiga metodeyang dapa dipergunakan untuk memberikan materi pelajaran mengingat kosa kata bahasa Inggris, yaitu metode awal-tengah, metode awal-akhir, dan metode tengah-akhir. Metode awal-tengah adalah pemberian materi pelajaran secara klasikal berupa kosa kata bahasa Inggris di awal pertemuan dan diulangi df tengah pertemuan. Metode awar akhir adalah pemberian materi pelajaran secara klasikal berupa kosa kata bahasa Inggris of awal pertemuan dan diulangi di akhir pertemuan. Metode tengah-akhir adalah pemberian materi pelajaran secara klasikal berupa kosa kata bahasa Inggris di tengah pertemuan dan diulangi di akhir pertemuan.

Ketiga metode penyajian materi pelajaran di atas secara teoretis mempunyai efektivitas yang berbeda. Menurut teori de cay. kelupaan terjadi karena lamanya waktu antara menerima dengan usaha memanggil kembali suatu informasi atau karena tidak terpakainya informasi tersebut. Hal ini 
terjadi karena pemrosesan informasi meninggalkan jejak dalam jaringan syaraf, yang ketika tidak digunakan akan seperti suatu jalur yang kabur (Solso, 1991). Chauhan, Zimbardo, dan Ruch (dalam Alsa, 1996) berpendapat bahwa semakin lama waktu untuk memanggil bahan yang sudah dipelajari, semakin banyak bahan yang dilupakan karena terjadi pemudaran. Metode awal-akhir dan metode tengah-akhir menekankan jarak waktu yang pendek dalam menyajikan materi pelajaran yang berarti mengatasi kelupaan yang disebabkan oleh interval waktu ketika pemberian materi pelajaran dengan usaha mengingat kembali materi pelajaran yang telah diterima.

Kelebihan metode awal-akhirdan metode tengah-akhir adalah tidak terjadi interferensi retroaktif karena setelah pengulangan materi pelajaran secara klasikal, individu tidak mempelajari bahan yang lain. Menurut Teori Interferensi, ingatan yang lain dapat menghalangi usaha untuk mengingat suatu bahan yang menjadi target untuk diingatsebelumnya. Sorenson, Zimbardo dan Ruch (dalam Alsa, 1995) mengatakan bahwa banyaknya isi interval berkor elasi negatif dengan ingatan, artinya semakin banyak isi interval maka semakin lemah ingatan seseorang. Hal ini tërjadi karena jejak-jejak ingatan menjadi berbaur satu dengan yang lain sehingga membuat individu menjadi lupa. Pada metode awal-akhir dan met ode tengah-akhir tidak terjadi interferensi retroaktif karena setelah pengulangan pemberian materi pelajaran secara klasikal, individu tidak mempelajari bahan yang lain.

Dengan demikian metode tengah-akhir dapat mengurangi kemungkinan terjadi kelupaan, baik disebabkan oleh jarak waktu pernberian materi pelajaran dengan usaha mengingat kembali materi pelajaran yang telah diterima maupun disebabkan oleh interferensi retroaktif.

\section{HIPOTESIS}

Berdasarkan uraiandi atas, hipotesis yang diajukan dalam penelitian ini adalah ada perbedaan efektivitas metode penyajian materi pelajaran, yaitu metode awal-akhir, metode awal-tengah, dan metode tengahakhir tehadap kemampuan anak prasekolah mengingat materi pelajaran berupa kosa kata bahasa Inggris. Metode tengah-akhir akan menghasilkan skor yang lebih tinggi daripada metode awal-akhir dan metode awal-tengah.

\section{ME TODE}

\section{Subjek Penelitian}

Subjek penelitian ini adalah santri Madtasah Diniyah Al Qur'an Aisyiah (MDAA) Tegalrejo, Yogyakarta yang berusia 5-6 tahun, belum pernah mengikuti kursus bahasa Inggris, dan betum pemah menerimapelajaran bahasa inggris di sekolah.

Jumlah santri yang mengikuti penelitian sebanyak 35 anak, tetapi 4 anak tidak dapat mengikuti secara penuh sehingga subjek yang disertakan dalam analisis data sebanyak 31 anak yang ter diri dari 14 laki-laki dan 17 perempuan.

\section{Alat Penelltian}

Alat-alat yang digunakan dalam penelitian ini adalah:

1. Tes Kemampuan Mengingat Kosa Kata Bahasa Inggris. Tes dalam penelitian ini terdiri dari tiga buah tes yang merupakan tes sejajar (alfernate-form). yaitu Tes Kemampuan Mengingat Kosa Kata Bahasa Inggris 1 (Tes 1), Tes Kemampuan Mengingat Kosa Kata Bahasa Inggris 2 (Tes 2), Tes Kemampuan Mengingat Kosa Kata Bahasa inggris 3 (Tes 3). Penyusunan tes sejajar dilakukan dengan mendasarkan pada spesifikasi yang sama,yaitu tujuan ukur, 
batasan objek ukur dan operasionalisasinya, banyaknya butir soal, format butir soal, indikator-indikator perilakunya, juga kalau perlu taraf kesukaran butir soal (Azwar, 1992). Setiap tes terdiri dari 16 butir soal dengan masingmasing soal disediakan 4 atternatif jawaban yang betbentuk gambar. Setiap jawaban yang benar diskor 1 dan jawaban yang salah diskor 0 .

Tabel 1.

\section{Wes Kemampuan Mengingat Kosa Kata Bahasa inggris}

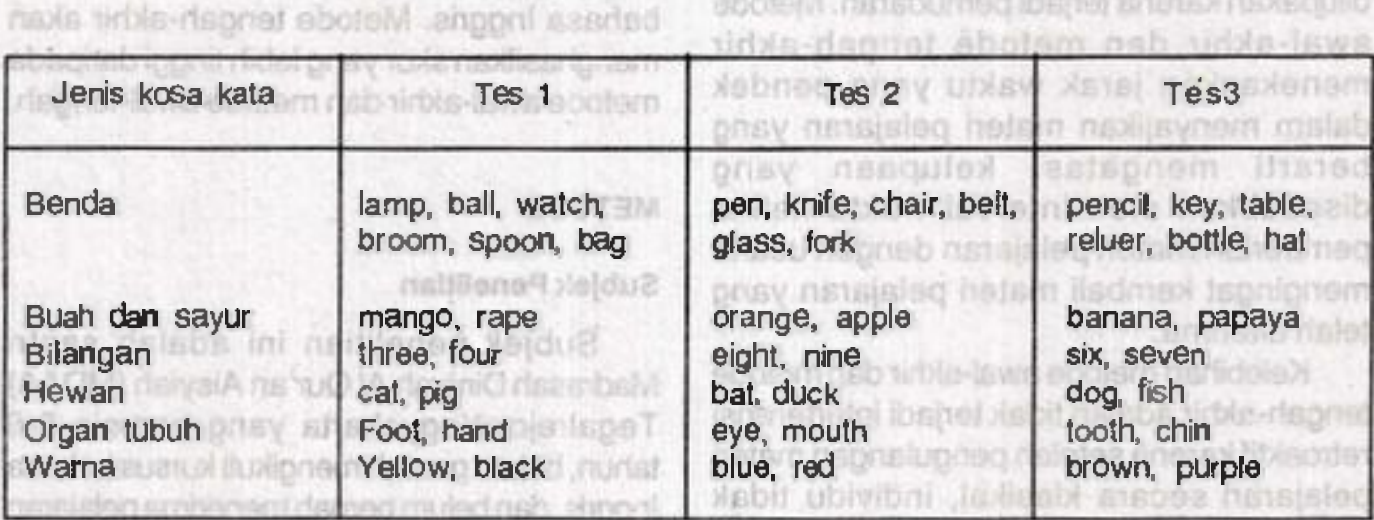

1. Angket. Angket disi oleh orangtua santri yang berisi pertanyaan-pertanyaan tentang kondisi lingkungan rumah subjek yang berkaitan dengan pengenalan bahasa inggris.

2. Gambar berukuran $30 \times 29 \mathrm{~cm}$ yang merupakan materi pelajaran kosa kata bahasa Inggris sebanyak 48 buah.

\section{a. Prosedur Pelaksanaan Eksperimen}

\section{Tabel 2. Pelaksanaan Eksperimen}

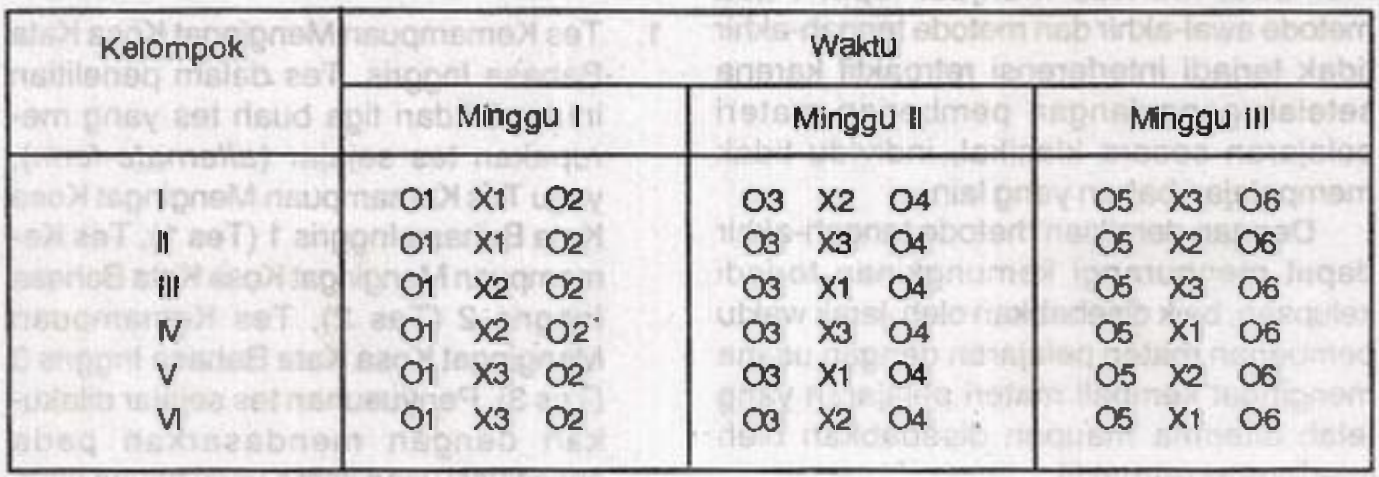




\section{Keterangan:}

Ot = Pemberian Tes 1 sebagai pre-test 1.

$C e$ = Pemberian Tes 1 sebagai post-test 1 .

$\infty=$ Pemberian Tes 2 sebagai pre-test 2 .

04 = Pemberian Tes 2 sebagai post-test 2 .

O5 = Pemberian Tes 3 sebagai pre-test 3.

06 = Pemberian Tes 3 sebagai post-test 3 .

$\mathrm{X} 1$ = Penyajian kosa kata bahasa Inggris d awal pertemuan dan diulangi d akhir pertemuan (metode awal-akhir).

$\mathrm{X}_{2}$ = Penyajian kosa kata bahasa Inggris di awal pertemuan dan diulangi di tengah pertemuan (metode awal-tengah).

$\mathrm{X}_{3}=$ Penyajian kosa kata bahasa Inggris di tengah pertemuan dan diulangi di akhir pertemuan (metode tengah-akhir).

Penelitian ini dilakukan secara eksperimental df ruang kelas MDAA Tegalerjo Yogyakarta dengan perincian 1 ruang untuk pemberian materi bahasa Inggris dan 3 ruang lainnya untuk pemberian materi lqra'. Pemberian materi lqra' memerlukan 3 ruang dengan perincian 1 ruang untuk kelompok yang diberikan perlakuan met ode awal-akhir, 1 ruang untuk kelompok yang diberikan perlakuan metode awal-tengah, dan ruang untuk kelompok yang diberikan perlakuan metode tengah-akhir. Subjek berada di ruangan sesuai dengan materi yang diberikan dan segera pindah ruangan ketika berganti materi.

Rancangan eksperimen yang digunakan dalam penelitian ini adalah pre and post-test design dengan saku kelompok subjek (withizsubject experiment) dan setiap subjek dikenakan seluruh perlakuan. Withinsubject design mempunyai masalah dengan order effect dan carry-over eff ectsehingga harus digunakan completecounterbalancinguntuk mengatasinya (Myers, 1987).

Perlakuan dalam penelitian ini terdiri dari tiga jenis, yaitu:

1. Melode awal-akhir: penyajian kosa kata bahasa Inggris secara klasikal di awal pertemuan selama 10 me nit, lalu membaca lqra' (buku pelajaran membaca AlQur'arı) secara privat dan menulis pelajaran yang dibaca dari buku lqra' selama 40 menit, lalu mengulangi materi kosa kata bahasa Inggris selama 10 menit.

2 Melode awal-tengah: penyajian kosa kata bahasa Inggris secara klasikal di awal pertemuan selama 10 menit, lalu membaca Iqra' (buku pelajaran membaca Al-Qur'an) secara privat dan menulis pelajaran yang dibaca dari buku lqra' selama 20 menit, lalu mengulangi materi kosa kala bahasa Inggris selama 10 menit, lalu membaca lqra' (buku pelajaran membaca Al-Qur'an) secara privat dan menulis pelajaran yang dibaca dari buku lqra' selama 20 menit.

3. Metode tengah-akhir: membaca Iqra' (buku pelajaran membaca Al-Qur'an) secara privat dan menulis pelajaran yang dibaca dari buku lqra' selama 20 menit, lalu penyajian kosa kata bahasa Inggris secara klasikal selama to menit, lalu membaca lqra' (buku pelajaran membaca AI-Qur'an) secara privat dan menulis pelajaran yang dibaca dari buku lqura' selama 20 menit, lalu mengulangi materi kosa kata bahasa Inggris selama 10 menit.

Pelaksanaan pemberian materi membaca dan menulis lqra' dilaksanakan dengan cara santri membaca Iqra' dan 
ustadz/ustadzah mendengarkan dan membenarkan kesalahan santri, sedangkan menulis lqra' dilakukan dengan cara santri menulis 1 halaman dari buku Iqra' yang dibacanya.

Materi bahasa Inggris diberikan secara klasikal dengan bantuan gambar berukuran $30 \times 29 \mathrm{~cm}$. Ustadz/ustadzah mengucapkan satu kosa kata bahasa Inggris sambil menunjukkan gambar yang sesuai dan memberitahu arkinya dalam bahasa Indonesia setelah itu santri menirukannya. Tiap satu kosa kata diberikan 2 kali sesuai prosedur di atas lalu dilanjutkan kosa kata berikutnya.

Satu kali pemberian materi bahasa Inggris dilaksanakan selama 10 menit untuk 16 kosa kata yang terdiri dari 6 kata benda, sedangkan kata buah dan sayur, bilangan, hewan, organ tubuh, dan warna masingmasin terdiri dari 2 kosa kata.

Penelitian berlangsung selama tiga minggu yang meliputi pemberian pre-test setiap hari Sabtu jam 14.30 WIB, pemberian perlakuan setiap hari Sen in jam 14.30-15.30 WIB, dan pernberian post-test setiap hari Senin jam 15.35 WIB.

\section{HASIL PENELITIAN}

Data yang terkumpul dianalisis dengan teknik anava amatan ulangan 1 -faktor dan uji t dengan menggunakan paket Seri Program Statistik dari Sutrisno Hadi dan Yuni Pamardiningsih (1990). Angka yang dipakai adalah skor delta yaitu selisih antara nilai pre-test dan post-test.

Hasil perhitungan analisis data dapat dilihat sebagai berikut:

Tabel 3. Rangkuman Nava Amatan Ulangan 1-Faktor Metode Awal-Akhir, Metode Awal-Tengah, dan Metode Tengah-Akhir

\begin{tabular}{|l|r|r|r|r|r|}
\hline Sumber Variasi & \multicolumn{1}{|c|}{ K } & db & MK & \multicolumn{1}{|c|}{ F } & \multicolumn{1}{c|}{ D } \\
\hline Antar A & 38,344 & 2 & 19,172 & 15,618 & $<0,01$ \\
Kasus & 271,312 & 30 & 9,044 & 7,367 & $<0,01$ \\
Galat & 73,656 & 60 & 1,228 & - & - \\
Total & 383,312 & 92 & & - & - \\
\hline
\end{tabular}

Tabel 4. Hasll Uji t Antar Ulangan

\begin{tabular}{|c|c|c|}
\hline Sumber & $T$ & $p$ \\
\hline A1-A2 & 4,241 & $<0,01$ \\
A1-A3 & $-1,032$ & $>0,05$ \\
A2-A3 & $-5,273$ & $<0,01$ \\
\hline
\end{tabular}

A1 = Melode awal-akhir

A2 = Metode awal-tengah A3 = Metode tengah-akhir 
Tabel5.DeskripsiskorDeita

\begin{tabular}{|c|c|c|c|c|c|c|}
\hline \multicolumn{1}{|c|}{ Metode } & $n$ & $\sum x$ & $\sum x^{2}$ & Ferata & SD & Rerata hipotetik \\
\hline Akhir-akhir & 31 & 291 & 2.831 & 9,387 & 1,820 & 8 \\
Awal-tengah & 31 & 254 & 2.170 & 8,194 & 1,721 & 8 \\
Tengah-akhir & 31 & 300 & 3.060 & 9,677 & 2,286 & 8 \\
\hline
\end{tabular}

Hasil penelitian menunjukkan bahwa terdapat perbedaan yang sangat signifikan antara metode awal-tengah, metode awalakhir, dan metode tengah-akhir. Analisis data dengan menggunakan anava amatan ulangan 1-faktor menunjukkan nilai sebesar

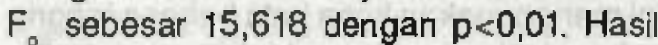
selanjutnya menunjukkan bahwa metode awal-akhir dan metode tengah-akhir menunjukkan hasil yang lebih baik daripada metode awal-tengah, sedangkan antara metode awal-akhir dan met ode tengah-akhir tidak menunjukkan perbedaan.

Uji t antar ulangan menunjukkan nilai t untuk met ode awal-akhir dan metode awaltengah sebesar 4,4241 dengan $p<0,01$, nilai I untuk metode awal-akhir dan metode tengah-akhir sebesar-1,032 dengan $p>0,05$ dan nilai t untuk metode awal-tengah dan metode tengah-akhir sebesar $-5,273$ dengan $p<0,01$. Semua metode efektif untuk mengajarkan kosa kata baru, dalam hal kosa kata bahasa Inggris, di Taman Kanak-kanak Al-Qur'an karena rerata skor setiap metode lebih besar daripada mean hipotetik.

\section{DISKUSI}

Hasil penelitian ini memberikan bukti empirik metode penyajian kosa kata baru, dalam hal ini kosa kata bahasa Inggris, yang tepat bagi anak prasekolah yang menjadi santri Taman Kanak-kanakAI-QUr'an (TKA).
Hasil analisis data menunjukkan terdapat perbedaan yang sangat signifikan antara metode awal-akhir, met ode awal-tengah, dan metode tengah-akhir. Metode awal-akhirdan metode tengah-akhir terbukti lebih efektif dibanding metode awal-tengah.

Pemberian materi pelajaran dengan metode awal-akhir dan metode tengah-akhir berarti menghilangkan pengaruh interferensi retroaktif tetapi hal ini tidak terjadi pada pelaksanaan metode awalntengah. Pelaksanaan post-test yang dilakukan setelah akhir pertemuan menyebabkan ingatan subjek tidak dicampuri oleh materi lain. Materi kosa kata yang disajikan of akhir pertemuan langsung direkognisi dalam post-testtanpa dihalangi oleh ingatan materi pelajaran lain. Hat yang berbeda terjadi pada pelaksanaan metode awal-tengah. Subjek belajar materi lain, yaitu membaca dan menulis lqra' sebelum pelaksanaan post-test sehingga jejak-jejak ingatan yang ada pada subjek menjadi berbaur dan membuat subjek menjadi lupa. Hal ini membuat metode awal-akhir dan metode tengah-akhir lebih baik daripada metode awal-tengah. Hasil penelitian ini sesuai dengan penelitian yang dilakukan Howe (1995) yang menggunakan anak-anak usia 4 dan 6 tahun sebagai subjek penelitian yang menunjukkan bahwa subjek mudah terkena interterensi retroaktif pada ingatan jangka panjangnya.

Hasil penelitian juga menunjukkan bahwa tidak ada perbedaan antara metode 
awal-akhir dan metode tengah-akhir karena nilai t-nya sebesar $-1,032$ dengan $p>0,05$. $\mathrm{Hal}$ ini dapat disebabkan perbedaan interval waktu antara pernberian materi dan pengulangan pemberian materi terlalu sedikit. Pada metode awal-akhir, waktunya adalah 40 menit sedangkan pada metode tengah akhir adalah 20 menit. Perbedaan tersebut terlalu sedikit sehingga tidak memberi pengaruh terhadap ingatan anak prasekolah. Menurut Teori Decay, kelupaan akan semakin nyata dengan interval waktu yang panjang antara belajar dengan usaha memanggil kembali hasil belajar tersebut. Di samping itu, pada kedua metode tidak terjadi interferensi retroaktif. Pelaksanaan post-test pada kedua metode dilakukan setelah akhir pertemuan tanpa mengingat materi lain. Hal ini menyebabkan materi yang disajikan di akhir perternuan langsung direkognisi dalam post-testtanpa dihalangi oleh materi lain.

Semua metode menunjukkan rerata empirik lebih besar daripada rerata hipotetik yang berarti semua metode efektif untuk memberikan materi kosa kata bahasa Inggris of TKA. Terdapat beberapa faktor yang dapat mempengaruhi hal tersebut, yaitu pengulangan (rehearsal), materi ingatan, jarak waktu antara pelaksanaan pretest dan post-test, kriteria tugas, kesiapan untuk mengingat, dan cara penyajian.

Ketiga metode d atas merupakan metode yang menggunakan pengulangan (rehearsaly, baik untuk ingatan jangka pendek maupun ingatan jangka panjang. Ketiga metode memberi kesempatan subjek untuk mengulang materi untuk ingatan jangka pendek ketika dalam satu kali pemberian materi klasikal, satu kosa kata diberikan dua kali. Pengulangan juga dilakukan dalam ingatan jangka panjang, yaitu materi klasikal diberikan dua kali, di awal dan of akhir pertemuan, atau di awal dan di tengah pertemuan, atau di tengah dan $d$ akhir pertemuan. Menurut Atkinson dan Shiffrin (dalam Kintsch, 1997), pengulangan akan meningkatkan ingatan. Menurut Favell (dalam Steinberg, okk., 1991), belajar suatu informasi, misalnya kata-kata, matematika, peristiwa-peristiwa, puisi, dipermudah dengan cara yang khusus. Cara yang paling dasar adalah pengulangan secara verbal, mengulangi informasi, dan terus mengulanginya.

Faktor materi pelajaran juga mempengaruhi kemampuan subjek mengingat materi pelajaran. Menurut Cohen dan Boushfieló (dalam Sorenson, 1964) dan Kintsch (1970), bahan yang mempunyai arti tidak mudah dilupakan dan membantu dalam proses belajar kosa kata. Penelitian ini menggunakan kosa kata bahasa Inggris sebagai stimulus dan subjek merespon dengan cara menyilang jawaban yang cocok. Materi stimulus (kosa kata bahasa Inggris) dan materi respon (gambar) mempunyai kaitan karena materi respon merupakan arti dari materi stimulus. Keterkaitan ini menyebabkan materi tidak mudah dilupakan.

Jarak pelaksanaan pre-test dan posttest adalah dua hari, yaitu hari Sabtu dan Senin. Jangka waktu tersebut memungkinkan terjadi carry-over effect. Menurut Azwar (1992), carry over-effect dapat terjadi sebagai akibat semacam latihan yang dialami subjek ketika mengerjakan tes pertama kali. Pada pelaksanaan tes kedua, subjek akan mengerjakan tes dengan lebih baik karena pengalamannya ketika pertama kali mengerjakan tes. Pada penelitian ini rerata empirik yang berada di atas mean hipotetik dapat disebabkan subjek mempunyal pengalaman ketika mengerjakan pretest of hari Sabtu sehingga dapat mengerjakan post-test of hari Senin dengan lebih baik.

Subjek dalam penelitian ini mengguna. kan rekognisi. Menurut Matlin (1989) dan Jenkins (dalam Smalt, 1990), mengingat 
kembali informasi yang telah diberikan akan lebih mudah dilakukan dengan rekognisi (mengenai kembali) daripada dengan recail (memanggil kembali).

Intensi mengingat suatu materi akan mempengaruhi kemampuan ingatan seseorang. Thisted dan Remmers (daiam Sorenson, 1964) membuktikan bahwa ingatan yang baik akan terjadi pada siswa yang mempunyai kesiapan mengingat materi yang dipelajari. Intensi mengingat pada eksperimen ini terjadi ketika subjek diberitahu bahwa setiap hari Senin akan dilaksanakan tes bahasa Inggris. informasi ini membuat subjek melakukan persiapan psikologis berupa intensi mengingat setiap akan dilaksanakan tes.

Cara menyajikan materi dalam bentuk gambar juga memperkuat ingatan subjek. Menurut Shepard (dajam Levin dan Alewn, 1976) dan Paivio (dalam Slavin, 1991), kata yang disajikan dalam bentuk gambar iebih kuat diingat daripada yang disajikan secara verbal. Penelitian yang dilakukan Astuti (1996) juga membuktikan bahwa metode gambar lebih efektif daripada metode bercerita daiam meningkatkan pemahaman kosa kata baru pada anak prasekolah.

Faktor-faktor seperti dijelaskan di atas kemungkinan memberikan kontribusi terhadap tingkat efektivitas metode sehingga seluruih metode terbukti efektrif sebagai metode penyajian kosa kata bahasa inggris.

Terdapat beberapa hal yang perlu diperhatikan yang berkaitan dengan kemumian skor tes, yaitu perilaku subjek selama tes dan kegiatan belajar subjek di rumah.

Pelaksanan pre-test dan post-festtelah diupayakan dapat menghasiikan skor tes yang murni yaitu dengan mengatur tempat duduk sehingga satu meja dipakai oieh satu subjek dan diawasi oleh dua guru tetapi terdapat beberapa subjek yang melihat pekerjaan temannya. Di samping itu, subjek sering mengucapkan jawaban ketika menjawab tes yang seharusnya dijawab secara tertulis waiaupun tester sudah menyampaikan prosedur menjawab soal. Menurut Hurlock (1980), pelanggaran yaitu bentuk-bentuk ringan dari menyaiahi peraturan atau perbuatan yang keliru, sering diiakukan pada tahun-tahun prasekolah karena ketidaktahuan anak atau lupa bahwa periiakunya tidak dibenarkan oleh keiompok sosial, atau ketidakpatuhan anak-anak prasekolah adaiah cara manrik perharian orang lain, atau disebabkan kebosanan. Oieh karena itu, terdapat kemungkinan skor tes subjek bukan merupakan kemampuannya yang murni.

Kegiatan belajar subjek d rumah dapat mempengaruhi kemurnian hasil tes karena subjek dapat belajar kembaii materi pelajaran yang teiah diberikan. Orangtua juga dapat mempengaruhi kemurnian hasil tes dengan menyuruh subjek belajar bahasa Inggris di rumah. Data dari angket menunijukkan bahwa subjek belum pernah mendapat pelajaran bahasa inggris, baik d rumah maupun di sekoiah, tetapi ketika mengetahui akan dilaksanakan tes, orangtua dapat memberi pelajaran bahasa inggrs agar anaknya dapat mengerjakan tes.

\section{SIMPULAN DAN SARAN}

Berdasar hasil penelitian dapat disimpulkan bahwa pemberian materi kosa kata bahasa Inggris secara kiasikal dapat dilakukan dengan metode awai-akhir, metode tengah-akhir, atau metode awal-tengah tetapi materi akan iebih kuat diingat bila meng. gunakan metode awal-akhir atau metode tengah-akhir.

Jarak waktu antara pelaksanaan pre-test dan post-test daiam penelitian ini adalah dua hari sehingga terdapat kemungkinan terjadi carry-over effect. Penelitian selanjutnya disarankan mengurangi kemungkinan tersebut dengan memperpanjang waktunya. Di 
samping itu, perlu juga diteliti faktor-faktor lain misalnya minat belajar, tingkat sosial ekonomi, dan pengontrolan terhadap faktor tingkat kecerdasan dan jenis kelamin. $~$

\section{DAFTAR PUSTAKA}

Alsa, A. 1996. Studi Eksperimental tentang Pengaruh Interferensi dan Rehearsal terhadap Retensi pada Belajar Matematika Siswa Kelas 5 Sekolah Dasar. Jumal Psikologi, No.2, 55-66. Yogyakarta: Fakultas Psikologi UGM.

Astuti, R.S. 1996. Perbedaan Efektivitas antara Metode Cerita dan Metode Garnbar dalam Meningkatkan Pemahamana Kosa Kata Baru pada Anak Prasekolah. Skripsi (tidak diterbitkan). Yogyakarta: Fakultas Psikologi UGM.

Azwar, S. 1992. Reliabilitas dan Validitas. Yogyakarta: Sigma Alpha.

Howe. M.L. 1995. Interference Effects in Young Children's Long Term Retention. Journal of Developmental Psychology. 31, (4) 579-596.

Hurlock, E. 1991. Perkembangan Anak Jilid L (Terjemahan). Jakarta: Erfangga.

Kintsch, W. 1997. Learning, Memory, and Conceptual Processes. New York: John Wiley \& Sons, Inc.

Levin, J., and Alieb, L. 1976 Cognitive Leaming in Children: Theories and Strategies. New York: Holt, Rinehart and Winston, Inc.

Matlin, M.W. 1989. Cognition. Second edition. New York: Holt, Rinehart and Wirston, Inc.
Myers, A. 1987. Experimental Psychology (2nd ed.) California: Brooks/Cole Pubishing Company.

Nuryanto, F. 1997. Reorientasi dan Reformasi Kebjjaksanaan Pembelajaran Baasa Inggris di Indonesia. Pidato Pengukuhan Guru Besar (tidak diterbitkan). Yogyakarta: Fakultas Pendidikan Bahasa dan Sastra IKIP Yogyakarta.

Scarr, S., Weimberg, R.A; and Levine, A 1986. Understanding Development. Orlando: Hartcourt Brace Jovanovich, Publishers.

Slavin, R.E. 1991. Educational Psychology: Theory into Practice (3rd ed.). New Jersey: Prentice-Hall, Inc.

Small, M.Y. 1990. Cognifive Development. New York: Hartcourt Brace Jovanovich, Publishers.

Solso, R.L. 1991. Cognitive Psychology (3ro ed.). Boston: Allyn and Bacon.

Sorenson, H. 1964. Psychology in Education. New Defhi: Tata McGraw-Hill Publising Co., Ltd.

Steinberg. L., Belsky, $\mathcal{J}_{\text {; }}$ and Mayer, R.B. 1991. If ancy, Childhood, and Adolescence. Developmental in Context. New Jersey: McGraw-Hill, Inc. Suara Merdeka. 1996. TK Al-Qur'an, Agenda Permasalahannya. Dalam Suara Merdeka. 1 Juli 1996. Semarang.

Suara Muhammadiyah. 1997. Telah Lahir Generasi Qur'ani. Dalam Suara Muhammadiyah. No. 23, 14-15. Yogyakarta.

$$
++
$$

